\title{
The Way of Clusters Uprising and Development in the Region (By the Example of The Petrochemical Cluster in the Republic of Tatarstan)
}

Tsertseil J.S.

\author{
Kazan (Volga region) Federal University, 18, Kremlyovskaya Street, Kazan,
}

Repablic of Tatarstan, Russian Federation, 420008

\section{Doi:10.5901/mjss.2014.v5n18p125}

\begin{abstract}
In the context of international economics globalization and markets consolidation forming cluster systems appears to be one of the main components in growth of competitive capacity of enterprises in a region. In terms of science a theory of cluster development being of particular interest as the synthesis of concepts concerning location of economic activity and a company's competitive advantage makes possible to explain rapid emergence of cluster formations in different industry sections of the region. That is why the necessity of formulating appropriate corporate strategy for the companies- participants of the cluster can make provision for rise in the cost of an enterprise in postindustrial economy. On the other hand, practical utilization of cluster approach to substantiate a company cost escalation in the presence of competition can be considered as a tool for development of economics in the region. At the same time utilization of classic cluster systems in postindustrial economy appears to be not sufficiently effective.
\end{abstract}

Keywords: cluster, regional cluster pattern, a region competitive ability, petrochemical cluster.

\section{Introduction}

The work suggests the pattern of the regional cluster formed under the stimulus of the cluster theory being elaborated by such scientifical men as E. Bergman, H. Gassler, E. Dakhmen, D. Jereffi, E. Liemer , A. Marshall, M. Porter, S. Rummer, F. Feldman, M. Enright.

M.E. Porter defines a cluster "as a geographically proximate group of interconnected companies, suppliers, service providers and associated institutions in a particular field, linked by externalities of various types,......basic feature of regional and national economies, with an important influence on innovation, competitiveness and economic performance."[6]

S. Stern defines a cluster "as a groups of related industries operating in a given location". [3]

Among the Russian researchers engaged in cluster theory elaboration we cannot but mention E. S. Akopova. N. E. Barsukova, E.A. Bogdanova, M.V. Vinokurova, M.P. Voinarenko, R.K. Gazimagomedov, A.V. Ermishina, K.V. Korshunova, A.N. Kudinov, S.V. Lozinsky, L.S. Markov, V.A. Naumov, J.V. Osipova, M.R. Safiullin, I.S. Fyodorova, I.S. Ferova, F.G. Khamidullin and others.

The theory of cluster development is the synthesis of concepts related to the location of economic activity and a company's competitive advantage that stipulates rapid emergence of cluster formations in different industry sections of the region.

"While at a (narrow) industry level firms may complete for a given pool of recourses, the cluster environment that surrounds an industry will increase the pool of competitive recourses and reduce the barriers of entry for new firms. Strong regional cluster enhance the range and diversity of entrepreneurial start-up opportunities, while also reducing the costs of starting a new business "[4]

«Industries located within a strong cluster are associated with higher employment, growth, a finding which is robust across different clusters in the region as well as the strength of the cluster in geographically adjacent regions. Strong clusters also foster growth in wages, the number of establishments, and patenting.» [3]

"Regional economic development has been seen as a product and a process. It is the product of economic development - for example, measured job, wealth, investment, standard of living and working conditions. It is the process - for example, industry support, infrastructure, labor force and market development. Generally increases or improvements in these measures are equated with economic development." [9]

However, the extent of studying the process of enterprise value formation in terms of cluster idea in the certain 
region is not consistent. Moreover, the role and place of intangible assets and institutional factors within the system of incluster relations seem to be underexplored. To enquire into the above questions follow-up studies are necessary.

\section{Theory}

With a view to implement the principle of brought-to-focus development suggesting a concentrated location of financial, administrative-and-managerial, human and other resources in "back-up" regions, the problem of cluster formations development on the territory of Tatarstan region is being thoroughly studied since 2006. To this effect the concept of cluster forming and development in the Republic of Tatarstan was elaborated by OJSC Innovation and Production technology park «ldea» under the guidance of Russian Academy of Sciences.

At the first stage of elaborating the concept of cluster forming and development in the Republic of Tatarstan mainly theoretic aspects of the given problem have been worked out including: definition of the «cluster» notion, its characteristics, philosophy of development and risks emerging at the project realization. At defining the notion of «cluster» the following comprehensions were also outlined:

- «densely located according to the rule of geographical distribution» within the context of Tatarstan means that the center of balance and the centre of attraction are geographically located inside the region;

- interoperation of «interdependent companies» brings to transaction costs depreciation at the level of the cluster and hence, we see the effect of synergism.

- «competitive but along with carrying out conjoint work» means that competition takes place in view of cooperation in production factors perfection to gain advantages both on the regional and international markets.

The properties of cluster as an economic category were also enumerated as follows:

- as a precondition for clusters emerging serve regional production complexes formed in centrally planned economy that is why they shall be revealed but not brought into being;

- characterization of the process of added value forming at interoperating of enterprises and infrastructure to determine their share in total added value amount.

The second stage was devoted to defining peculiar attributes of a cluster:

- utilization of common base for enterprises delivering factors of production;

- availability of participating companies - non-conventional suppliers;

- availability of a competitive advantage (joining the cluster means an increase in added value);

- resting upon the common base - an organization supplying factors of production;

- availability of common infrastructure;

- legal independence of cluster subjects.

Cluster policy was formulated at the third stage. Cluster policy implies the selection of priorities in industry sectors and territorial location as well as target development of cluster infrastructure and determining the volumes of financing and tax adjusting where the state rather gives additional opportunities than imposes limitations $[2,5,9,11]$.

The fourth stage dealt with outlining the risks leading to deterioration in cluster performance:

- elimination of difference in business conditions and introduction of artificial constraints for work processes;

- risk of artificial cluster arrangement;

- restriction of competition;

- preservation of a competitive sector within cluster frames;

- the problem of efficient control over cluster forming;

- lowering inner competitive ability in the Republic due to non natural actions;

- lack of research institutions, design and experimental organizations as well as corporate structures in most of the industries of the Republic;

- putting investments in innovative technologies but not into end developments

As can be seen from the above at present a theoretical base reflecting the essence and content of the notion «cluster» was clearly formulated for the regional level of the Republic. A conclusion can be made that «cluster» is the system of geographically interrelated companies and organizations mutually cooperating based on a single strategy of corporate management. As a result of this cooperation they gain competitive advantage due to inner and outer institutional environment what, in particular, brings about value added formation and rise in the company cost and investment attractiveness. 


\section{Results}

The given pattern shows that the petrochemical cluster makes possible to watch key interrelations in the sector of industry having a profound effect on a competitive ability.

As shows Fig. 1. «Petrochemical cluster pattern in the Republic of Tatarstan» at present the region possesses the integral structure of petrochemical cluster represented by the main participants.

Notation conventions:

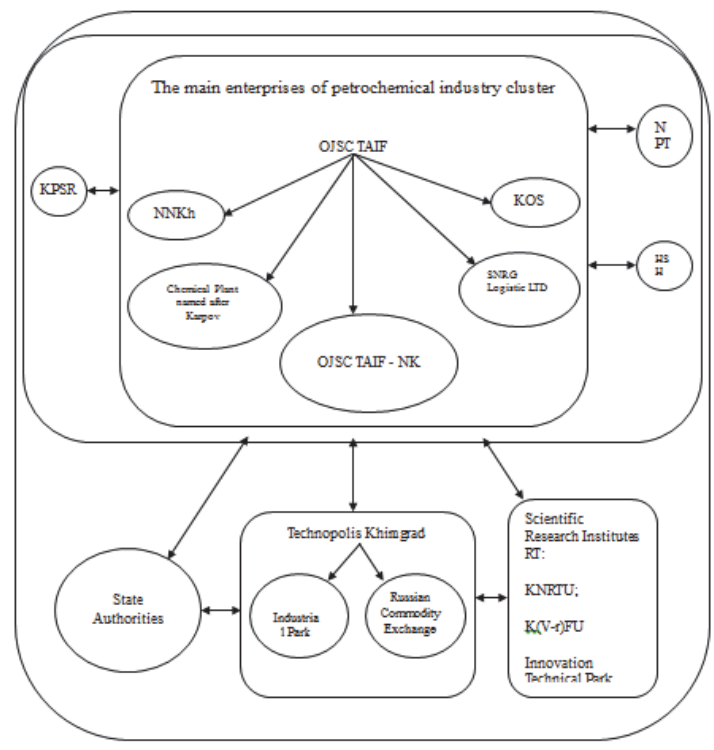

OJSC TAIF - Open joint stock company «TAIF»

NNKh - OJSC «Nizhnekamskneftekhim»

KOS - OJSC «Kazanorgsynthez»

NPTC - OJSC «Nizhnekamsk Plant of Technical Carbon»

HSH - OJSC «Nizhnekamskshina»

KPSR - OJSC «Kazan Plant of Synthetic Rubber»

OJSC TAIF - NK - OJSC TAIF "The Plant of oil processing"

KNRTU - Kazan National Research Technological University

K(V-r)FU - Kazan (Volga region) Federal University

Fig. 1. «Petrochemical cluster pattern in the Republic of Tatarstan».

In the context of rapid world economic globalization complexes having formed in the consequence of integration processes or clusters play an increasingly important part in rival products development $[1,8,10]$. The Republic of Tatarstan happened to possess the following petrochemical cluster shown in table 1.

Table 1: Participants of petrochemical cluster in the Republic of Tatarstan

\begin{tabular}{|c|l|l|}
\hline Group & Cluster participants & Industry sector \\
\hline 1 & $\begin{array}{l}\text { NPTC, OJSC TAIF - NK, NNKh, HSH, KOS, Chemical Plant } \\
\text { named after Karpov, SNRG Logistic LTD. KPSR }\end{array}$ & Mineral industry, processing industry \\
\hline 2 & Scientific Research Institutes & Service industries \\
\hline 3 & Technopolis Khimgrad & Infrastructure \\
\hline 4 & State Authorities & Legal and regulatory framework \\
\hline
\end{tabular}




\section{Conclusions}

The present work formulates the principle of petrochemical cluster pattern development in the Republic of Tatarstan. The enterprises of the cluster are grouped according to kinds of their activity: process industries, services sector, education, state sector. The main peculiarity and key characteristics of the cluster being formed is the availability therein a nucleus company systemically important for the processes of integration, elaboration and introduction of a single corporate strategy. "Governance has an important role to play. It is the role of directors to exercise oversight and challenge management on the way it runs the business. Management has to balance: strategic risks, tactical risks, operational risks.» [7]

Nowadays the strategic principle of action implemented by the investment company OJSC TAIF is focused on petrochemical industry advancement. OJSC TAIF cumulative volume of investments in the sphere of petroleum production, processing and petrochemistry before 2012 made 200 billion rubles and consequently production volume amounted to 400 billion ruble. (Table 2.)

Table 2: The main performance indices (balance sheet ratio) of OJSC TAIF group over a period of 2010-2012

\begin{tabular}{|l|c|c|c|c|c|}
\hline Indices, billion rubles & 2010 & 2011 & 2012 & Rate of growth in 2011 & Rate of growth in 2012 \\
\hline $\begin{array}{l}\text { Gross operating income collected from sales of } \\
\text { goods, works and services. }\end{array}$ & 340 & 433.5 & 452.2 & 1.275 & 1.043 \\
\hline $\begin{array}{l}\text { Amount of investments in the enterprise capital } \\
\text { assets }\end{array}$ & 22 & 19.5 & 25.7 & 0.89 & 1.318 \\
\hline $\begin{array}{l}\text { Earnings before Interest, Taxation, Depreciation \& } \\
\text { Amortisation (EBITDA) }\end{array}$ & 54.2 & 67.3 & 84 & 1.24 & 1.248 \\
\hline Net Earnings & 33.3 & 42.5 & 59.4 & 1.276 & 1.398 \\
\hline
\end{tabular}

\section{References}

Gainova R.A., Shaidullin R.N., Safiullin L.N. and Maratkanova E.M. Infrastructural Component in Maintenance of Competitiveness of Region// World Applied Sciences Journal, 27(13), 2013, pp. 97-101.

Markov, V.A., Bagautdinova, N.G., Yashin, N.S. Improvement of instruments of the state cluster-based policy in the contexts of economic entities interrelation asymmetry // World Applied Sciences Journal, 27(13), 2013, 130-134.

Safiullin L.N., Ismagilova G.N., Gallyamova D.Kh., Safiullin N.Z. 2013. Consumer benefit in the competitive market // Procedia Economic and finance. Volume 5, pp. 667-676 (DOI: 10.1016/S2212-5671(13)00078-6).

Dekiado M., Porter M.E., Stern S. Cluster, Convergence and Economic development. Institute for Strategy and Competitiveness. Harvard Business School. 2011. pg. 32.

Glebova I.S., Sadyrtdinov R. and Rodnyansky D. Impact Analysis of Investment Attractiveness of the Republic of Tatarstan on Fixed Investments of its Leading Companies // World Applied Sciences Journal 26 (7): 911-916, 2013.

Bagautdinova, N.G., Tsvetkova, G.S., Novenkova, A.Z. The interaction of formal and informal market institutes // World Applied Sciences Journal, 27(13), 2013, 58-61.

Pierce J., Robinson R. Strategic Management - 12-th edition. -St. Petersburg.: Peter, 2013. - 560 p-s.

Kirshin I.A., Datsyk A.A., Titov A.V. Forecasting the Dynamics of an Innovative Cycle. - World Applied Sciences Journal (Economics, Management and Finance). - 2013. - №27. - P. 197 - 201.

Porter M.E. The Economic Performance of Regions. Institute for Strategy and Competitiveness. Harvard Business School. 2003. pg. 562.

Safiullin L.N., Ismagilova G.N., Safiullin N.Z., Bagautdinova N.G. The development of welfare theory in conditions of changes in the quality of goods and services (2012) World Applied Sciences Journal 18, pp. 144-149.

Stimson R.J., Stough R.R., Roberts B.H.. Regional Economic Development: analysis and planning strategy. Second edition. Springer Berlin Heidelberg New York. 2006. pp. 4 